\title{
THEORETICAL ARC OF GOALKEEPER POSITION IN TEAM SPORTS. CASE STUDY: FOOTBALL
}

\author{
${ }^{1}$ AGH University of Science and Technology, Faculty of Mining Surveying and Environmental Engineering, Krakow, Poland, \\ and ${ }^{2}$ The State University of Technology and Economics, Jaroslaw, Poland
}

Keywords: analysis of goal defence in a team game, strategic conditions for position selection, optimization of the gate defence place selection, geometrical place of the maximum chance

\begin{abstract}
The current position of the goalkeeper in football is a function of the course of action and each momentary position of the ball. The goalkeeper monitors the action and the place of a potential shot; however, this shot on goal is a random event. That is why it is so important to take a position in the closest goal area that takes account of the random nature of the ball's direction.

The basic principle of the strategy is to create equal opportunities for defence on the left and on the right. Using the language of geometry, this position can be placed on the bisector of the angle at which the goal can be seen from the potential shooting position.

At the beginning of this research paper, the advantages associated with the goalkeeper slightly coming off the goal line along this bisector have been presented, as well as certain restrictions related. Further in the article, the task of determining the theoretical curve along which the goalkeeper should move has been undertaken. Geometrically correct, but unfavourable in practical terms, two circles, Cassini oval, a composition of the arcs of two circles and a segment of the straight line as well as the arc of the ellipse have been considered.

In the second part of the paper, the point analysis of the goalkeeper's position has been changed into real conditions - a defence zone equal to the goalkeeper's arms' reach has been taken into account. For these conditions, a curve has been determined, composed of two arcs of the circles and the arc of the ellipse. A detailed analysis has led to the conclusion that the discrepancy between such an arc and a homogeneous arc of the ellipse is practically negligible. Therefore, both arcs: the one composed of parts and the homogeneous one of the ellipse - can be accepted as rational and practically alternative.

In this research paper, the problem has been analysed from the geometric point of view, taking into consideration a shot on goal that is a random event for the goalkeeper. The proposed theoretical goalkeeper arc ensures an optimal position, taking account of the shots coming from different directions, from the zone close to the penalty area.
\end{abstract}

\section{TEORETYCZNY LUK POZYCJI BRAMKARZA W GRACH ZESPOLOWYCH NA PRZYKLADZIE PIŁKI NOŻNEJ}

Słowa kluczowe: analiza obrony bramki w grze zespołowej, uwarunkowania strategiczne wyboru pozycji, optymalizacja wyboru miejsca obrony bramki, miejsce geometryczne maksymalnej szansy

\footnotetext{
Abstrakt

Bieżące ustawienie bramkarza w grze w piłkę nożną jest funkcją przebiegu akcji i każdej chwilowej pozycji rozgrywania piłki. Bramkarz śledzi akcję i pozycję potencjalnego strzału, natomiast strzał do bramki jest w jego odbiorze zdarzeniem losowym.
} 
Dlatego tak bardzo ważne jest zajęcie takiego miejsca w najbliższej strefie bramki, które uwzględnia losowy charakter kierunku piłki.

Podstawową zasadą strategii postępowania jest stworzenie równej szansy obrony po stronie lewej i prawej. Stosując język geometrii, można tę pozycję umiejscowić na dwusiecznej kąta, pod jakim widać światło bramki z potencjalnej pozycji strzeleckiej.

$\mathrm{Na}$ początku niniejszego artykułu zostały przedstawione korzyści z niewielkiego wyjścia z bramki wzdłuż tej dwusiecznej oraz pewne ograniczenia z tym związane. W dalszej części podjęto zadanie wyznaczenia teoretycznej krzywej, po jakiej powinien się poruszać bramkarz. Rozpatrzono poprawne pod względem geometrycznym, ale niepraktyczne dwa okręgi, owal Cassiniego, złożenie łuków dwóch okręgów i odcinka prostej oraz łuk elipsy.

W drugiej części artykułu punktową analizę pozycji bramkarza zamieniono na warunki realne - uwzględniono strefę obrony równą rozpiętości ramion. Dla tych urealnionych warunków została wyznaczona krzywa utworzona z dwóch łuków okręgów i łuku elipsy. Szczegółowa analiza doprowadziła do wniosku, że rozbieżność pomiędzy tak zbudowanym złożonym łukiem a jednorodnym łukiem elipsy jest praktycznie zaniedbywalna. Dlatego te obydwa łuki: złożony z części i jednorodny łuk elipsy - mogą być zaakceptowane jako racjonalne i praktycznie alternatywne.

W niniejszym artykule problem był rozważany od strony geometrii, z uwzględnieniem strzału do bramki odbieranego przez bramkarza jako zdarzenie losowe. Zaproponowany teoretyczny tuk bramkarza zapewnia optymalną pozycję uwzględniającą strzały padające z różnych kierunków, ze strefy bliskiej pola karnego.

\section{INTRODUCTION TO THE BASIC PRINCIPLES OF DEFENCE STRATEGY IN FOOTBALL}

The authors of this research paper have attempted to determine a continuous set of goalkeeper positions that provide optimal conditions for defending shots taken from various directions and distances. During the analyses the sought continuous set of positions will be referred to as the goalkeeper arc .

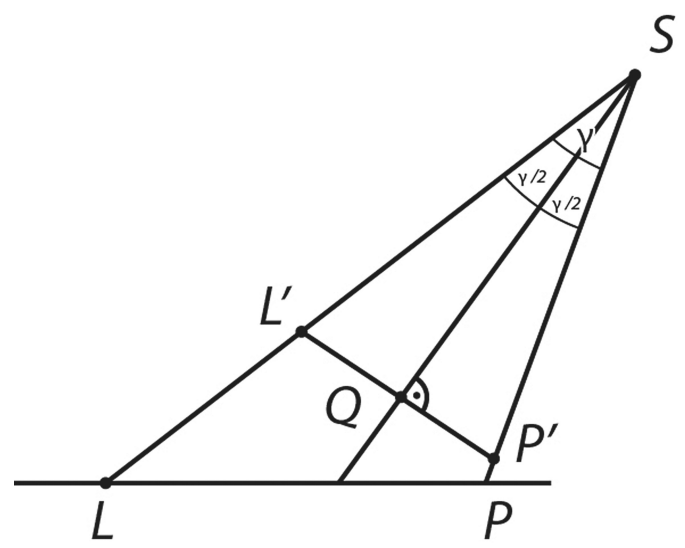

Fig. 1. The optimal position of the goalkeeper at point $Q$ ensuring equal distances $Q L^{\prime}$ and $Q P^{\prime}$ to the arms of the angle $\gamma$, determined by the shooting point $S$ and the boundary points of the goal $L$ and $P$; position $Q$ is on the bisector of this angle

Rys. 1. Optymalna pozycja bramkarza w punkcie $Q$ zapewniająca równe odległości $Q L$ 'i $Q P$ ' do ramion kąta $\gamma$, wyznaczonego przez punkt strzału $S$ i punkty graniczne bramki $L$ i $P$; pozycja $Q$ znajduje się na dwusiecznej tego kąta
The goal defence strategy consists in adopting a position that guarantees optimal fulfilment of geometric and physical conditions in relation to deterministic and random processes that occur in football. The defence strategy consists of six basic principles that the goalkeeper must follow:

1. Taking a certain shooting position by a player of the attacking team is a real event that is controlled by the goalkeeper. However, the direction

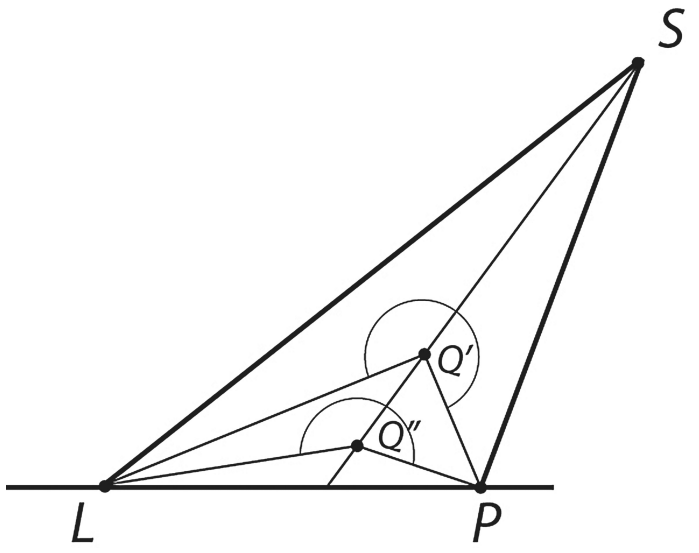

Fig. 2. Coming off the goal line ensures a greater re-entrant angle at point $Q$ ' to punch the shot out of the goal than the angle at point $Q$ ", and it protects better against temporary loss of control over the ball - at a greater distance from the goal line

Rys. 2. Wyjście z linii bramkowej zapewnia większy kąt wklęsły przy punkcie $Q$ ' do odbicia strzału poza światło bramki niż kąt przy punkcie $Q$ " oraz lepiej zabezpiecza przed chwilową utratą kontroli nad piłką - w większej odległości od linii bramkowej 
of the shot is a random event. Therefore, it is logical for the goalkeeper to take a position that gives him the same chance to defend the goal from both sides (Fig. 1).

2. It is favourable for the goalkeeper to come off the goal line slightly towards the shooting point $S$ to reduce the defence area $L P^{\prime}$ ' (Fig. 1).

3. Coming off the goal line also creates an additional favourable situation - in the event of the ball being punched (parried), the goalkeeper has a larger angle to direct the ball to bypass the goal (re-entrant angle $L Q^{\prime} P$ ) (Fig. 2). However, when he is closer to the goal line - the angle is smaller (angle $L Q$ " $P$ ). Also, in the event of insufficient blocking of the ball after a strong shot, he has a larger field to re-capture it at point $Q$ ' (triangle $L Q ' P$ is larger than triangle $L Q " P)$.

4. Coming off the goal line along the bisector of the angle $\gamma$ towards the shooting point $S$ (Fig. 1) admittedly shortens the field of defence $L$ ' $P$ ', but reduces the time of observation of the ball trajectory and leaves less time for a reaction.

5. Coming off the goal line too far creates the danger of taking a shot in a high arc, above the goalkeeper. Such a shot is called a lob.

6. Coming off the goal line too far creates further threats - the goalkeeper, to some extent, loses the situational intuition of the goal line $L P$ relative to his current position; he cannot look backwards while controlling the game. Also, the goalkeeper's interventions should generally take place at the position or while moving forward, never while backing up.

From the following principles of defence strategy, there are certain conclusions that can be drawn: the determination of the set of goalkeeper positions is influenced by geometric and physical factors - often opposite ones. Let us analyse these factors in a broader way, attempting to arrive at theoretical conclusions, and confront them with practical experience.

\section{GEOMETRIC RELATIONSHIPS - FAVOURABLE AND UNFAVOURABLE ZONES}

Figure 3 illustrates an example that will allow us to make the first step in the analysis. The goalkeeper defends the goal $L P$. The shooting point $S$ is distant from

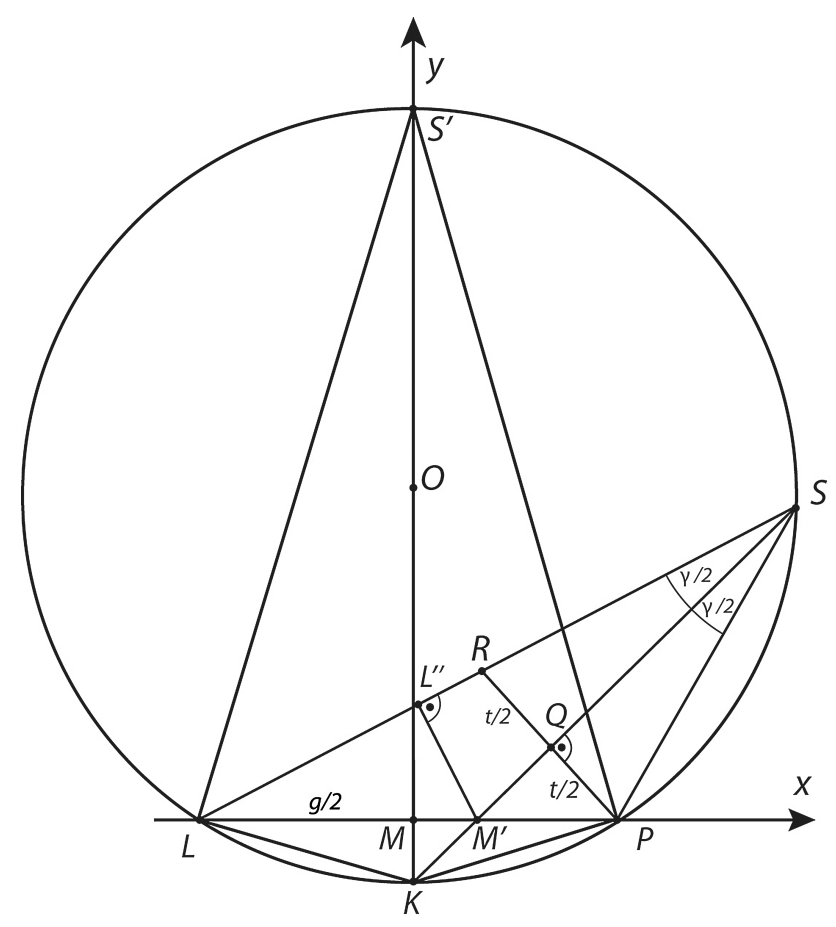

Fig. 3. Analysis of the goalkeeper's position on the bisector of the angle with a vertex at the shooting point $S$, whose arms are based on the boundary points of the goal $L$ and $P$. Taking position at point $Q$ is more favourable than at point $M^{\prime}$ because it ensures a regular defence zone and a safe distance from the goal line $L P$

Rys. 3. Analiza pozycji bramkarza na dwusiecznej kąta o wierzchołku w punkcie strzału $S$, którego ramiona są oparte na punktach granicznych bramki $L$ i $P$. Zajęcie pozycji w punkcie $Q$ jest bardziej korzystne niż w punkcie $M^{\prime}$, ponieważ zapewnia regularną strefę obrony oraz bezpieczną odległość od linii bramkowej $L P$

the longitudinal axis of the pitch $S^{\prime} M$ (and also the bisector of the segment $L P$ ). The bisector of the angle $L S P$ with a vertex at the shooting point $S$, intersects the goal line at point $M^{\prime}$. The goalkeeper's position at this point is favourable due to the principles 5. and 6. presented above. Point $M^{\prime}$ is the farthest from the shooting point $S$, so it leaves the most time to observe the ball's path and to intervene.

However, this position of the goalkeeper is unfavourable due to the principles 1 . and 3.:

- On the right hand side of the position $M^{\prime}$, there is a segment M'P to be defended along the goal line; on the left hand side, there is a segment $M^{\prime} L$ " forming a right angle with the $S L$ arm of the angle, 
at which the goal can be seen from the shooting point $S$. Both segments are of different lengths and cross the angle bisector $S M^{\prime}$ ' at different angles.

- The defence at point $M^{\prime}$, belonging to the goal line segment $L P$, creates a risk in the event of insufficient blocking of the ball and temporary loss of control over it.

Considering the two negative factors mentioned above, it can be assumed that the goalkeeper's favourable position is point $Q$ located on the bisector of the angle with the vertex at the shooting point $S$ (and based on points $L$ and $P$ ) and on the line perpendicular to this bisector and passing through point $P$, which is the goal boundary point, closer to the shooting point $S$. Position $Q$ is favourable because it meets the strategy conditions 1., 2. and 3., and at the same time does not significantly violate the principles $4 ., 5$. and 6. :

- It ensures defence of the same distance on the left and on the right sides, the segments $Q R$ and $Q P$, marked as $t / 2$ in Figure 3 are equal.

- As a result of the goalkeeper slightly coming off the goal line towards the shooting point $S$, an isosceles triangle $R S P$ is formed, whose base $R P=t$ is smaller than the sum of the segments $M^{\prime} L$ " and $M^{\prime} P$.

- Point $Q$ is sufficiently distant from the goal line and this position is a protection against the case of temporary loss of control over the ball.

Let us now consider the geometric locus of point $Q$ for any direction of a shot on goal. An arc of a circle has been drawn through the boundary points of the goal $L$ and $P$ and through the shooting point $S$, whose centre $O$ is placed on the bisector of the goal line and, at the same time, on the longitudinal axis of the pitch (Fig. 3). The angle bisector $S Q$ intersects the arc of the circle at point $K$, creating two chords $K L$ and $K P$ of identical length. The equal lengths of the chords and the location of point $K$ on the perpendicular bisector of the goal line are based on the theorem about angles inscribed in a circle: all angles inscribed in a circle and subtended by the same chord are equal.

It should be noted that the triangle $K Q P$ is a right triangle: the sides $K Q$ and $Q P$ always form a right angle, and the hypotenuse $P K$ is the chord of the circle passing through points $L, K, P$ and $S$. If we circumscribe the second circle on the vertices of the triangle $K Q P$
(Fig. 4), the hypotenuse $P K$ will be the diameter of this circle because the right angle inscribed in this circle is subtended by it. The centre of the circle is point $O^{\prime}$ located in the middle of the segment $P K$.

Because we have assumed that the segment $R P$, defending the goal, is always perpendicular to the bisector of the angle $R S P$, the geometric locus of point $Q$ will be the arc of the circle with the centre at point $O$ ', located on the segment $P K$.

Similarly, for the shooting point located on the other side of the longitudinal axis of the pitch, the geometric locus of the goalkeeper's position will be the arc of the circle with the centre at point $O$ ", located on the segment $K L$.

Now let us consider what the location of the centre of the circle circumscribed on the triangle $K Q P$ is, for an exemplary shooting position located at the corner of the penalty area. In the coordinate system illustrated in Figure 4, in the first quadrant of the system, the coordinates of this point are as follows:

$$
x=20.16 \mathrm{~m}, y=16.50 \mathrm{~m} .
$$

The coordinates of the circle centre can be calculated from the right triangle $M P K$, which, like the triangle $K P Q$, is subtended by the diameter $P K$. The $X$ coordinate of point $O$ ' can be easily read from Figure 4 - it is equal to one quarter of the length of the goal line $L P$ (also marked as $g$ ):

$$
x_{O^{\prime}}=1 / 4 \mathrm{~g}=1.83 \mathrm{~m},
$$

because the segment $O^{\prime} H^{\prime}$ is the axis of symmetry of the arc of the circle based on points $M$ and $P$.

In order to determine the $y$ coordinate of the point $O$, from the triangle $M P K$, we have to find the relationship of the angle $\gamma$ with the vertex at the shooting point $S$ with the angles at the base in the isosceles triangle $L P K$. First, we need to determine the angle $\gamma$ as the angle difference $\alpha$ and $\beta$ (Fig. 4)

$$
\begin{gathered}
\tan \alpha=\frac{x_{S}-x_{L}}{y_{S}}, \\
\tan \beta=\frac{x_{S}-x_{P}}{y_{S}}, \\
\gamma=\alpha-\beta, \\
\gamma=\operatorname{atan} \frac{x_{S}-x_{L}}{y_{S}}-\operatorname{atan} \frac{x_{S}-x_{P}}{y_{S}} .
\end{gathered}
$$




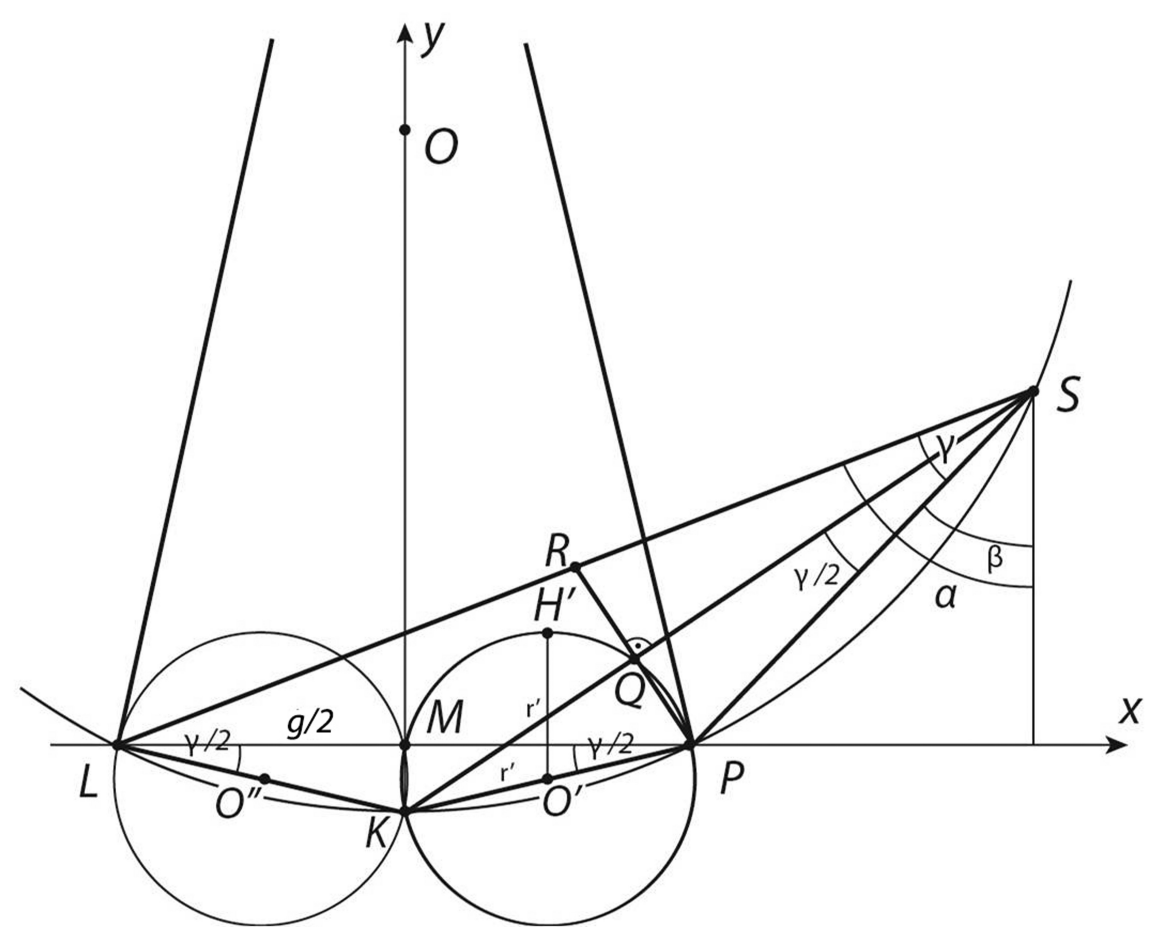

Fig. 4. Determining the geometric locus of point $Q$ for any direction of a shot on goal. This locus is the point on the arc of the circle with the centre at point $O$ ', whose diameter $K P$ is also the chord of the arc of the circle at the centre at point $O$ passing through points $L, K, P$ and $S$

Rys. 4. Wyznaczenie miejsca geometrycznego położenia punktu $Q$ dla dowolnego kierunku strzału do bramki. Tym miejscem jest punkt na łuku okręgu o środku w punkcie $O$ ', którego średnica $K P$ jest jednocześnie cięciwą łuku okręgu o środku w punkcie $O$, przechodzącego przez punkty $L, K, P$ i $S$

The angle $\gamma$ for the shooting point $S$ located in the corner of the penalty area is equal to $10,28^{\circ}$.

It is to be noticed that the angle $K L P$ is equal to $\gamma / 2$ because it is inscribed in the circle passing through points $L, K, P$ and $S$ and is subtended by the same chord $P K$ as the angle $K P S$. The opposite angle at the base of the isosceles triangle $L P K$ is also equal to $\gamma / 2$. In order to determine the $y$ coordinate of point $O^{\prime}$, one must calculate the side $K M$ of the right triangle $K M P$ in which the angle $\gamma / 2$ and the cathetus $P M$ equal to half the length of the goal $g / 2$ are known. The length of the segment $K M$ is also the $y$ coordinate of point $K$ with a negative sign

$$
\tan \frac{\gamma}{2}=\frac{K M}{\frac{\mathrm{g}}{2}}, \quad K M=\frac{\mathrm{g}}{2} \tan \frac{\gamma}{2} .
$$

The $y$ coordinate of point $O$ ' is equal to half the segment $K M$ with a negative sign. Having performed the calculations, we can collate the complete coordinates of points $O$ ' and $O$ ':

$$
\begin{aligned}
& x_{O^{\prime}}=+1.83 \mathrm{~m}, \quad y_{O^{\prime}}=-0.16 \mathrm{~m}, \\
& x_{O^{\prime}}=-1.83 \mathrm{~m}, \quad y_{O^{\prime \prime}}=-0.16 \mathrm{~m} .
\end{aligned}
$$

Based on the results obtained, several practical conclusions can be drawn. Due to the fact that the angle $\gamma / 2$ for the analysed example assumes a small value, equal to slightly more than $5^{\circ}$, the triangle $M P K$ is slim. Point $O$ ' does not come much off the line passing through points $L$ and $P$. The radius $r^{\prime}$ of the circle with the centre at point $O^{\prime}$ is equal to $1.84 \mathrm{~m}$, which is close to the fourth part of the dimension of the goal $L P$ (equal to $1.83 \mathrm{~m}$ ). The maximum value of the $y$ coordinate of the arc of the circle is $1.68 \mathrm{~m}$ at point $H^{\prime}$.

It should be concluded that, from a theoretical point of view, the favourable set of goalkeeper positions, i.e. the geometric locus of point $Q$, is the arc of the circle with the centre at point $O$ ', located between points $P$ and $M$ and passing through point $H^{\prime}$. However, it will be demonstrated in further considerations, that from a practical point of view, this thesis is only valid in a certain section of the arc $P H^{\prime} M$. 
It should be noted that in the case of the shooting point $S$ located on the longitudinal axis of the pitch, the goalkeeper should take a position at point $M$, on the goal line (Fig. 4). Thus, the positions of the goalkeeper on the arcs that are favourable in the case of wing shots become unfavourable for shots taken from the zone close to the longitudinal axis of the pitch. Then, we are dealing with an approach to the goal line (or even alignment with this line), which significantly contradicts the principles 2. and 3.: the case of temporary loss of control over the ball on or near the goal line is a great threat, because only a horizontal angle, slightly less than $180^{\circ}$, remains for the ball to be punched.

However, the biggest disadvantage of such a geometric set of the goalkeeper's positions built on two arcs of the circles (Fig. 4), is its singularity (lack of smoothness of the course) in the central zone of the goal, i.e. a "sharp" shape that is difficult to imitate in practice.

\section{CORRECTION OF THE ARC, OPTIMISATION OF ITS SHAPE}

Let us attempt to determine the arc of the goalkeeper's position that:

- smooths the convergence of the two arcs in the middle zone of the goal,

- maintains a smooth and regular shape of the arcs in this zone,

- largely satisfies with the current principles for wing shots - it does not diverge much from the previously discussed arcs of the circles (Fig. 4).

Let us explore the possibility of using a curve called a Cassini oval, or rather its special case called cassinoid. The definition of a Cassini oval is similar to the definition of an ellipse. An ellipse is the geometric locus of points for which the sum of the distances from the focal points is a constant, while in the case of a Cassini oval - the constant $a^{2}$ is the product of the distances from the focal points, separated by $2 b$ from each other. This slight difference in definition builds a fourth degree curve chart whose shape may differ significantly from the ellipse. Depending on the parameters adopted, a Cassini oval may have an ellipse-like shape, may have a narrowing in the central part (Fig. 5) or may form two separate closed curves. The Cassini oval equation in the Cartesian system takes the following form:

$$
\left(x^{2}+y^{2}\right)^{2}=2 b^{2}\left(x^{2}-y^{2}\right)+a^{4}-b^{4},
$$

where $a$ and $b$ are the parameters that shape the curve. Depending on the mutual relationship of $a$ and $b$, the Cassini oval takes one of the above-mentioned shapes. For the case when the parameter $a$ is greater than $b$, it has a narrowing (waist) and four points with extreme values of the $Y$ coordinate.

Let us look at whether the shape of the Cassini oval with a narrowing, stretched at the goal's boundary points $L P$ (Fig. 5), eliminating the singular convergence of two circles illustrated in Figure 4, has the sought features described above. The Cassini's oval smooths the convergence of the two arcs, creates a smooth transition between them and removes defects of singularity at the convergence of the arcs at point $M$ (Fig. 4). However, its shape may not be very clear for the goalkeeper, and difficult to put into practice.

The unusual shape of the Cassini's oval prompts us to consider the simplest case: connecting the two arcs of the circles (Fig. 4) with a straight line parallel to the goal line and tangent to them (Fig. 6). In the discussed typical case, where the shooting point $S$ is located in the corner of the penalty area, the straight line passing through points $H^{\prime}$ and $H^{\prime \prime}$ has the equation $y=1.68$.

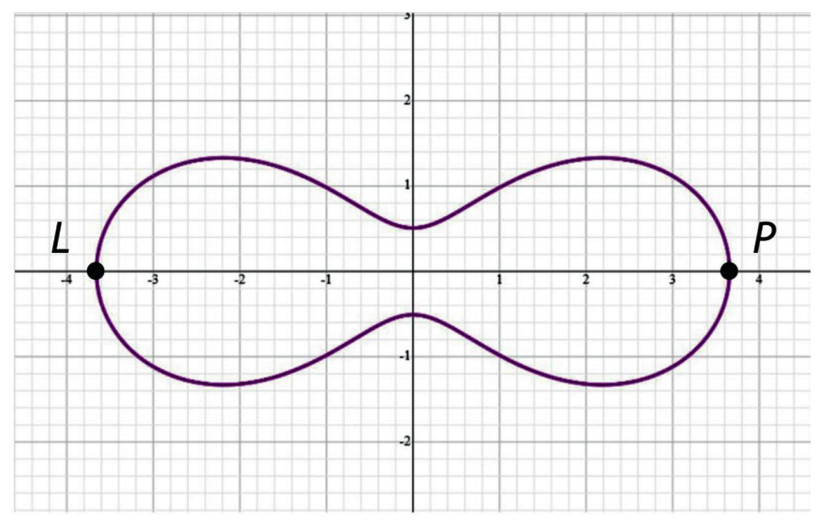

Fig. 5. The Cassini oval connecting the two arcs on the left and right in a smooth and regular way, removing the singularity occurring in the middle zone of the goal, illustrated in Figure 4. The curve expressed by Formula (2), built into the base of the goal $L P$ (equal to $7.32 \mathrm{~m}$ ), has been drawn for the parameters: $a=2.61 ; b=2.56$.

Rys. 5. Owal Cassiniego łączący w płynny i regularny sposób dwa łuki po lewej i prawej stronie, usuwając osobliwość występującą w środkowej strefie bramki, widoczną na rysunku 4. Krzywa wyrażona wzorem (2), wbudowana w prześwit bramki $L P$ (równy 7,32 m), została wykreślona dla parametrów: $a=2,61 ; b=2,56$ 


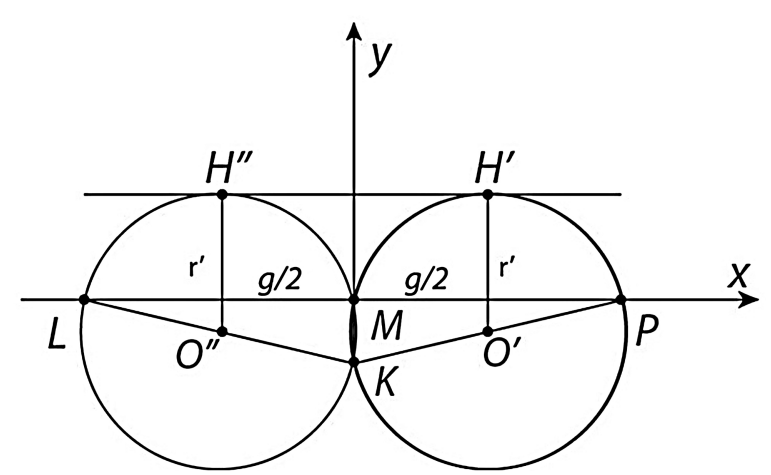

Fig. 6. The arc of the goalkeeper's position as a composition of two arcs of the circles $P H^{\prime}$ and $H^{\prime \prime} L$ with centres at points $O^{\prime}$ and $O$ "' and the segment $H^{\prime} H^{\prime \prime}$

Rys. 6. Łuk pozycji bramkarza jako złożenie dwóch łuków okręgów $P H^{\prime}$ i $H^{\prime \prime} L$ o środkach w punktach $O$ ' $i O$ " oraz odcinka $H^{\prime} H^{\prime \prime}$

This case is clearer than the Cassini's oval; it does not create, however, one smooth, and thus more practi$\mathrm{cal}$, arc of the goalkeeper's position. However, this position system has one very useful application. It frequently happens that a ball is passed from one wing to another. Then, the goalkeeper ready to defend shots from the zone on one side must immediately take a position on the arc on the other side of the perpendicular bisector of the goal line. He then chooses the shortest path, marked by a straight line passing through points $H^{\prime}$ and $H^{\prime \prime}$.

These considerations lead to the suggestion that a fragment of the arc of the ellipse could be a favourable goalkeeper arc. The advantage of such a solution would be the uniformity of this curve - such an arc is not a combination of circles and a straight line. The ellipse is a curve recognisable in everyday experience, and a regular one, so it is not difficult to use it in practice.

Two parameters are required to build the ellipse: the lengths of both semi-axes. The longer axis is determined unambiguously - it should be equal to the goal width $(7.32 \mathrm{~m})$. The left and right vertices of the ellipse should correspond to the left and right boundary points of the goal, respectively.

When determining the length of the shorter axis, we will refer to life experience. When observing expert goalkeepers, it is noticeable that when they control the course of the game in a zone that is close to the longitudinal axis of the pitch, they occupy a position off the goal line equal to about $1 / 3$ of the width of the goal area rectangle. Some goalkeepers move farther away from

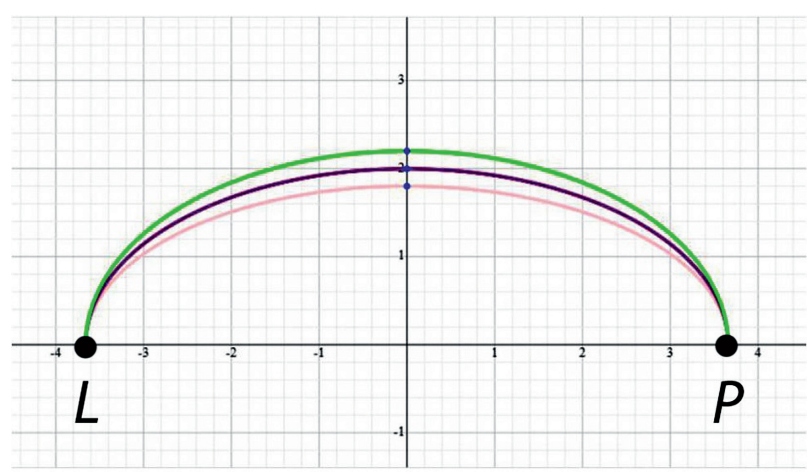

Fig. 7. Half of the ellipse as the goalkeeper arc stretched at the goal's boundary points $L, P$; the Figure illustrates three arcs with a shorter half-axis equal to $1.8 \mathrm{~m}, 2.0 \mathrm{~m}$ and $2.2 \mathrm{~m}$ Rys. 7. Połowa elipsy jako łuk bramkarza rozpięty na punktach granicznych bramki $L P$ - rysunek przedstawia trzy łuki o krótszej półosi równej 1,8 m, 2,0 m i 2,2 m

the goal line, reaching up to half that width. Due to the fact that the longer side of the goal area rectangle is 5.5 meters away from the goal, the third part of this distance is $1.83 \mathrm{~m}$. Figure 7 illustrates the arc of the ellipse with a shorter half-axis length equal to $1.8 \mathrm{~m}$ and, additionally, arcs with half-axes lengthened to $2.0 \mathrm{~m}$ and $2.2 \mathrm{~m}$.

From the ellipse equation, the variability of its curvature can be determined. This variability is easily noticeable in Figure 7 - the largest curvature occurs in the zone of the left and right vertices. Then, it gradually decreases as it approaches the upper vertex. This decreasing curvature of the ellipse creates a certain discrepancy with the conclusions drawn after the analyses, illustrated in Figure 4. It was then found that the geometric locus of the favourable position of point $Q$ is the arc of the circle with the centre at point $O$ '. The mentioned discrepancy results from the fact that the circle has a constant curvature, and the ellipse has a variable one. Therefore, it seems right to keep the arcs of the circles, at least in the left and right zones of the goal, as optimal positions for defending shots taken from the wings of the pitch.

\section{CONSTRUCTION OF A CURVE COMPOSED OF THE ARCS OF THE CIRCLES AND THE ARC OF THE ELLIPSE}

Let us attempt to form a curve that will be a combination of the arcs of the circles in the peripheral areas of the goal and the arc of the ellipse in the central 
zone. The arcs of the circles with the centres at points $O$ ' and $O$ " will run from the boundary points of the goal $P$ and $L$ to the straight lines forming $45^{\circ}$ angles with the $X$ axis and passing through the centres of the circles. Due to the symmetry relative to the $Y$ axis, it is enough to carry out further considerations in the first quadrant of the coordinate system.

A straight line passing through point $O$ ' with the coordinates $[+1.83:-0.16]$ and having the slope +1.00 , has the following form:

$$
y=x-1.99
$$

The equation for a circle with radius $r$ and centre at $O^{\prime}$ is as follows:

$$
(x-1.83)^{2}+(y+0.16)^{2}=1.84^{2}
$$

A straight line with the equation (3) intersects the circle at two points, of which the point in the first quadrant has the coordinates $(+3.13 ; 1.14)$. The equation of the tangent to the circle at this point has the form:

$$
y=-x+4.27
$$

Now we need to determine the parameters of the ellipse, which:

- has focal points located on the $X$ axis, symmetrical to the origin of the coordinate system,

- passes through the predetermined point of intersection of the straight lines of equations (3) and (5),

- the arc of this ellipse is tangent to the straight line (5) at the point $(+3.13 ; 1.14)$.

At $\left(x_{0}, y_{0}\right)$, the equation of the tangent to the ellipse $\frac{x^{2}}{a^{2}}+\frac{y^{2}}{b^{2}}=1$ with the semi-axes $a$ and $b$ has the following form:

$$
\frac{\mathrm{x} \mathrm{x}_{\mathrm{o}}}{a^{2}}+\frac{\mathrm{y} \mathrm{y}_{\mathrm{o}}}{b^{2}}=1
$$

After inserting the coordinates of the tangent point, we obtain the following equation:

$$
\frac{3,13 x}{a^{2}}+\frac{1,14 y}{b^{2}}=1,
$$

which, together with the equation of the tangent line to the circle (5), creates a system of two equations with two unknowns and the parameters $a$ and $b$. Both equa- tions lead to the construction of an ellipse that is tangent to the given straight line at a predetermined point and centrally located relative to the coordinate system.

To calculate the parameters of the ellipse that meets certain geometric conditions (the known centre and the point tangent to the straight lines which it must pass through), a portal calculation tool was used (Wolfram Alpha...). As a result of the calculations, the following values of the ellipse's semi-axis were obtained:

$$
\mathrm{a}=3.65, \quad \mathrm{~b}=2.21 \text {. }
$$

A smooth connection of the arc of the circle and the arc of the ellipse meeting the assumptions is illustrated in Figure 8.

A composition of the two arcs of the circles and the arc of the ellipse in the central zone creates an optimal and clear curve on which the goalkeeper should be standing to control shots coming from different directions and from different distances. However, in these theoretical considerations, we have treated the position of the goalkeeper as a point that belongs to the arc of the curve or a combination of the arcs. In real conditions, it should be taken into account that the goalkeeper, without changing his place, is able to defend a certain area that is within his arms' reach. Therefore, in the next stage of the considerations, the goalkeeper arc will be assigned practical features.

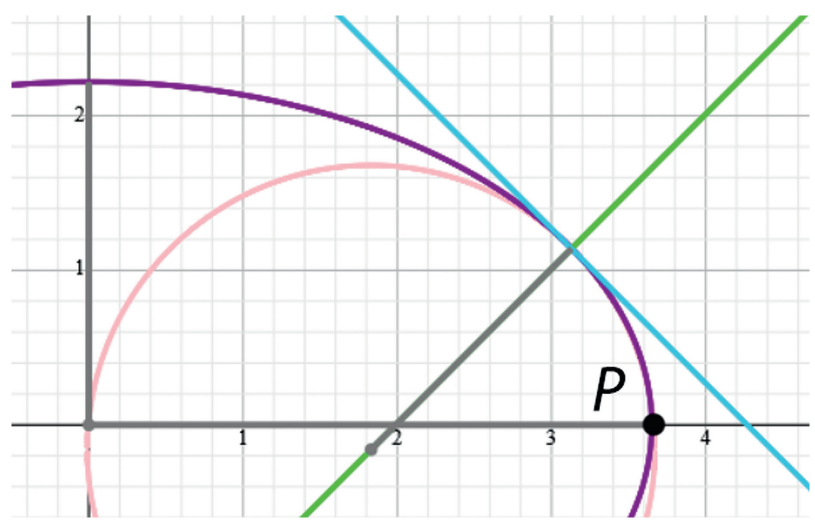

Fig. 8. The connection of the arc of the circle and the arc of the ellipse at the point of intersection of the circle with a straight line forming an angle of $45^{\circ}$ with the axis of the $X$ axis and passing through the centre of the circle

Rys. 8. Konstrukcja powiązania łuku okręgu z łukiem elipsy w punkcie przecięcia okręgu prostą tworzącą z osią osi $x$ kąt $45^{\circ}$ i przechodzącą przez środek okręgu 


\section{THEORETICAL ARC OF THE GOALKEEPER POSITION TAKING ACCOUNT OF THE REAL CONDITIONS OF THE GOAL DEFENCE}

Let us assume that the goalkeeper can defend with his arms stretched out a zone that is about $1.8 \mathrm{~m}$ wide, without changing his current position. The consequence of this practical assumption is reducing the goalkeeper arc. The previous arc, based on the boundary points of the goal $L$ and $P$, can be based on two points located on the goal line and shifted to the centre of the goal by $0.9 \mathrm{~m}$. It can be assumed that the previous end points of the arcs, $7.32 \mathrm{~m}$ away from each other, approach and are $5.52 \mathrm{~m}$ away. We shall adapt our current considerations to these realistic assumptions.

Using Formula (1), we shall calculate the angle $\gamma$ for this reduced segment of defence and for the shooting point $S$ located in the corner of the penalty area. As expected, the angle $\gamma$ decreases to $7.73^{\circ}$. As it was the case in Section 2, we calculate the coordinates of the centre of the circle $O$ ', which is the geometric locus of point $Q$ (Fig. 4) on the bisector of the angle $\gamma$ and on the line perpendicular to this bisector and passing through the boundary point of the reduced goal, from the side of the shooting point $S$. Thanks to the symmetry, we can determine the complete coordinates of points $O$ ' and $O$ ":

$$
\begin{aligned}
& x_{O^{\prime}}=+1.38 \mathrm{~m}, \quad y_{O^{\prime}}=-0.09 \mathrm{~m}, \\
& x_{O^{\prime \prime}}=-1.38 \mathrm{~m}, \quad y_{O^{\prime \prime}}=-0.09 \mathrm{~m} .
\end{aligned}
$$

The radius of the circle $r$, determined from the skinny right-angled triangle, which is the equivalent of the $M P K$ triangle (Fig. 4), is equal to the rounding of the fourth part of the reduced goal and is $1.38 \mathrm{~m}$.

Further calculations are analogous to those contained in the previous Section and due to the symmetry relative to the $Y$ axis, they will be limited to the first quadrant.

The straight line passing through point $O$ ' with coordinates $(+1.38:-0.09)$, having the slope +1.00 , has the following form:

$$
y=x-1.47,
$$

The equation for the circle with radius $r$ ' and the centre at $O^{\prime}$ is as follows:

$$
(x-1.38)^{2}+(y+0.09)^{2}=1.38^{2} .
$$

The line with equation (8) intersects the circle at two points, of which the point in the first quadrant has the coordinates $(+2.36 ;+0.89)$. The equation of the tangent to the circle at this point has the form:

$$
y=-x+3,25 .
$$

By inserting the coordinates $(+2.36 ;+0.89)$ into the equation (6) of the tangent to the ellipse, we obtain the following equation:

$$
\frac{2,36 \mathrm{x}}{a^{2}}+\frac{0,89 \mathrm{y}}{b^{2}}=1,
$$

which, together with the equation of the line tangent to the circle (10), creates a system of two equations with two unknown parameters $a$ and $b$. Both equations lead to the construction of an ellipse that is tangent to the given straight line at a predetermined point and centrally located relative to the coordinate system.

As in the previous chapter, portal calculation tools were used to calculate parameters of the ellipse (Wolfram Alpha...). The following values of the ellipse semi-axis were obtained:

$$
a=2.76, \quad b=1.69 \text {. }
$$

Figure 9 demonstrates the full structure of a smooth connection between the two arcs of the circle with the arc of the ellipse. Fragments of the arcs with positive $Y$ coordinate values will be used for further analysis

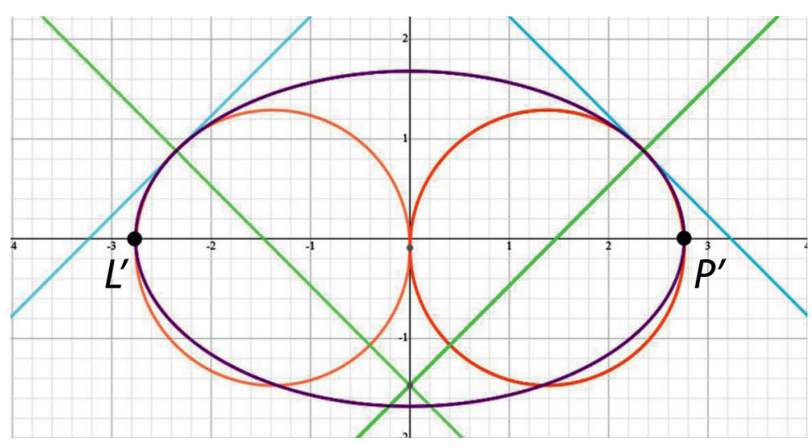

Fig. 9. Construction of the composition of the arcs of the circles and the arc of the ellipse for a reduced goal; the figure presents the circles, straight lines passing through the centres of the circles and tangent to the circles and the ellipse, as well as the ellipse itself

Rys. 9. Budowa złożenia łuków okręgów i łuku elipsy dla zmniejszonego światła bramki; rysunek przedstawia okręgi, proste przechodzące przez środki okręgów, styczne do okręgów i elipsy oraz elipsę 


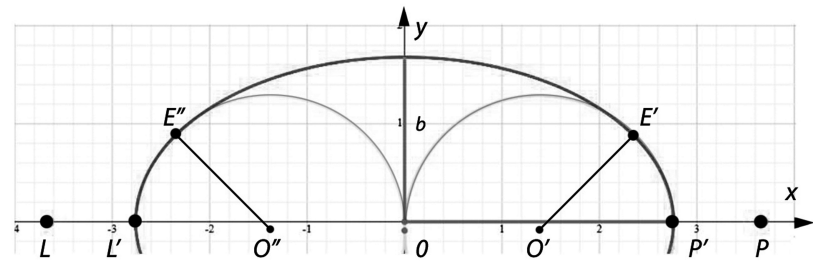

Fig. 10. The theoretical, optimal arc of the goalkeeper controlling the course of the game in the zone close to the penalty area, guaranteeing a favourable position for defending shots taken from various directions. Points $L$ and $P$ define the actual size of the goal, points $L^{\prime}$ and $P^{\prime}$ indicate a reduced range of positions, taking into account the practical defence zone with the width equal to the goalkeeper's arms' reach

Rys. 10. Teoretyczny, optymalny tuk bramkarza kontrolującego przebieg gry w strefie zbliżonej do granicy pola karnego, gwarantujący korzystną pozycję do obrony strzałów padających z różnych kierunków. Punkty $L$ i $P$ wyznaczają rzeczywisty wymiar bramki, punkty $L^{\prime}$ i $P^{\prime}$ wyznaczają zmniejszony zakres pozycji, uwzględniając praktyczną strefę obrony o szerokości zasięgu ramion bramkarza

(Fig. 10). This Figure illustrates the actual size of the goal $L P$ and the reduced range $L ' P$ ' resulting from the fact that the goalkeeper can control the zone within his arms' reach without changing his position.

The goalkeeper $\operatorname{arcs} P^{\prime}, E^{\prime}, E^{\prime}, L^{\prime}$ are composed of the two arcs of the circles $P^{\prime} E$ ' and $E$ '" $L$ ' with centres at points $O$ ' and $O^{\prime \prime}$ and the arc of the ellipse $E^{\prime} E^{\prime \prime}$, respectively. In Figures 9 and 10, a large convergence of the arcs of the circles $P^{\prime} E$ ' and $E$ ' $L$ ' with fragments of the arcs of the ellipse contained between these points is noticeable. The arcs of these figures almost overlap. It is worth analysing the differences between them analytically, because in the case of the values that are negligible from a practical point of view, it would be possible to replace the arcs of the circles and the arc of the ellipse with a uniform arc of the ellipse. The arc of the circle has a constant curvature, while the arc of the ellipse has a curvature increasing as it approaches the $X$ axis. Therefore, we shall take a closer look at the divergence between these two arcs in the zone closer to that axis in the direction parallel to the $X$ axis, i.e. with the fixed values of the $Y$ coordinate. The values of the coordinates and the discrepancies between them are contained in Table 1

The data contained in Table 1 indicate discrepancies that are negligible. Thus, it can be concluded that the composition of the three arcs illustrated in Figure 10 and one arc of the ellipse contained between points $L^{\prime}$ and $P^{\prime}$ can be treated as equivalent from a practical point of view.

\section{CONCLUSIONS}

A typical feature that distinguishes football from other team sports is a relatively small number of goals scored in football competitions. It is a consequence of numerous factors: the offside rule, defence tactics, training of players, as well as the position and efficiency of the goalkeeper. The changing position of the goalkeeper is a function of the course of the action and if this action takes place in the half of the defending team, each momentary position of the ball should correspond to a specific position of the goalkeeper. The goalkeeper monitors the action and the place of a potential shot. A shot on goal is a random event, though. That is why it is so important to take a position that takes account of the random nature of the ball's direction.

The basic principle of the strategy is to create equal opportunities for defence on the left and on the right. Us-

Tab. 1. Divergence between the arc of the circle and the arc of the ellipse in the zone close to the $X$ axis in [m]

Tab. 1. Rozbieżności przebiegu łuku okręgu i łuku elipsy w strefie bliskiej osi $x \mathrm{w}$ [m]

\begin{tabular}{|c|c|c|c|}
\hline $\begin{array}{c}\text { For straight lines parallel } \\
\text { to the } \boldsymbol{X} \text { axis } \\
\text { with the equation }\end{array}$ & $\begin{array}{c}\boldsymbol{X} \text { coordinate of the arc } \\
\text { of the circle }\end{array}$ & $\begin{array}{c}\boldsymbol{X} \text { coordinate of the arc } \\
\text { of the ellipse } \\
\text { the coordinates of the ellipse } \\
\text { and the circle }\end{array}$ & $\begin{array}{c}\text { Difference between } \\
+0.01\end{array}$ \\
\hline$y=0.3$ & 2.67 & 2.68 & +0.02 \\
\hline$y=0.2$ & 2.70 & 2.72 & +0.01 \\
\hline$y=0.1$ & 2.73 & 2.74 & 0.00 \\
\hline
\end{tabular}


ing the language of geometry, this position can be placed on the bisector of the angle at which the goal can be seen from the potential shooting position (Figs. 3 and 4).

At the beginning of this research paper, the advantages associated with the goalkeeper slightly coming off the goal line along this bisector have been presented, as well as certain related restrictions. Further in the article, the task of determining the theoretical curve along which the goalkeeper should move has been undertaken. Geometrically correct, but unfavourable in practical terms, two circles (Fig. 4), Cassini oval (Fig. 5), a composition of the arcs of two circles and a segment of the straight line (Fig. 6) as well as the arc of the ellipse (Fig. 7) have been considered.

In the second part of the paper, the point analysis of the goalkeeper's position has been changed into real conditions - a defence zone equal to the goalkeeper's arms' reach has been taken into account. For these conditions, a curve has been determined, composed of two arcs of the circles and the arc of the ellipse (Figs. 9 and 10). A detailed analysis has led to the conclusion that the discrepancy between such an arc and a homogeneous arc of the ellipse is practically negligible. Therefore, both arcs: the one composed of parts and the homogeneous one of the ellipse - can be accepted as alternatives.

The determined theoretical goalkeeper arc has a maximum distance from the goal line of $1.68 \mathrm{~m}$, which is the shorter semi-axis of the ellipse. This is $30 \%$ of the goal area width. Experienced goalkeepers can build their arc which is slightly larger, in the form of an ellipse with a shorter semi-axis equal to $1 / 3$ of the goal area width $(1.83 \mathrm{~m})$, or even larger. However, one should be aware of a slight increase in discrepancies in the peripheral zones of the arcs of the circles $L{ }^{\prime} E^{\prime}$, and $E^{\prime} P^{\prime}$ (Fig. 10). If the goalkeeper moves off the goal line further, there is a risk he might not be able to defend a shot over him (the so-called lob).
The length of the theoretical goalkeeper arc is approximately half the circumference of the ellipse with the semi-axes equal to $2.76 \mathrm{~m}$ and $1.68 \mathrm{~m}$, and it is $7.08 \mathrm{~m}$. In practice, the arc will be slightly shorter because the goalkeeper always has to keep a certain distance from the goal line. This will not result in the deteriorated defence of the peripheral areas of the goal $L L$ ' and $P P^{\prime}$ (Fig. 10).

In this research paper, the problem has been analysed from the geometric point of view, taking into consideration a shot on goal that is a random event for the goalkeeper. The proposed theoretical goalkeeper arc ensures an optimal position, taking account of the shots coming from different directions, from the zone close to the penalty area. This is, of course, one of several factors affecting the effective defence of the goal. In addition to these important principles of geometry in the zone close to the penalty area, the goalkeeper through his skilful action analysis, the ability to predict, his physical fitness and acquired experience must counteract the threats resulting from rotary shots, from continuous improvement of ball elasticity, from reduced air density on pitches located at higher altitudes above sea level and from unfavourable lighting. These are the factors that cannot be parametrised.

\section{REFERENCES}

[1] Barańska A., Eckes K.: Spatial Relations Between the Field of Play for Team Sports and the Target. Case Study: Football. Artykuł skierowany do druku.

[2] Galbraith P., Lockwood T. (2010): Things May Not Always Be as They Seem: The Set Shot in AFL Football. Australian Senior Mathematics Journal, vol. 24, no 2.

[3] Symbolab Math Solver, https://www.symbolab.com/graphing-calculator.

[4] Wolfram Alpha Mathematics, https://www.wolframalpha. com/examples/mathematics/. 